\title{
Osobno i privatno u pobožnosti biblijskog psalmista kao pojedinca
}

\author{
Danijel Berković \\ Biblijski institut, Zagreb \\ dberkovic@bizg.hr \\ Dean Slavić \\ Filozofski fakultet, Sveučilište u Zagrebu \\ dean.slavic@gmail.com
}

UDK: 27-242:27-27:2-18

Izvorni znanstveni članak

https://doi.org/10.32862/k1.14.2.4

\section{Sažetak}

U ovom se radu promišlja korelacija pojmova osobno i privatno u kontekstu osobne i privatne pobožnosti biblijskog psalmista. Elementi antropologije (srce, duša, lice) ovdje zauzimaju prvorazredno mjesto, posebno uvidom u biblijsko korištenje pojmova lice i duša (נפש i (מנה) (panah i nefeš), što uvelike korenspodira grčkom pojmu пробо $\omega \nu$ (prosopon) - osoba, persona (engl. person). Autori ustrajavaju na distinkciji pojmova osobno i privatno, ali prepoznaju uzajamnost i meduovisnost para: osobno - privatno. Primjereno ovom radu, autori se referiraju i na tekst svetog Pavla u njegovoj Himni ljubavi (1 Kor 13), gdje se zorno ističu aspekti osobnog i privatnog u dvojakoj ulozi, kako pasivnog tako i aktivnog aspekta pojedinca (subjekta). Rasprava rada slijedi mnogogodišnje diskusije i propitkivanja vezane uz distinkciju osobnosti i privatnosti, ali dodaje i svoj obol glede osobe i osobnosti, subjekta i subjektivnosti, ovdje u kontekstu biblijskog psalmista.

Ključne riječi: psalmist, osoba, osobno, subjekt, privatno, srce, lice, duša 


\section{Uvodne opaske}

Nije rijetkost da se na razini leksika poneki pojmovi uzimaju kao istoznačnice, kada to oni zapravo i nisu. Takav je slučaj s pojmovima osobno i privatno koji se ponekad uzimaju za istoznačnice (sinonime). Mada se semantička polja ovih dvaju pojmova u dijelu i preklapaju, ovi pojmovi sasvim sigurno nisu istoznačnice. Primjer distinkcije pojmova osobno i privatno ilustrativan je upravo u pobožnosti biblijskog psalmista. Na način da se osobna pobožnost psalmista očituje i u javnim vjerskim događanjima, ali će se ona, kako će se vidjeti, ponekad na osebujan način, manifestirati u njegovoj privatnosti.

U ovome članku prvo ćemo pobliže razlučiti i pojasniti pojmove kao što su osobno i privatno, a nakon toga poimanje pojmova subjekt i subjektivnost. Pažljivi čitatelj biblijskog Psaltira lako će se i sam naći u situacijama poistovjećivanja s biblijskim psalmistom pa će se toj problematici pridati posebna pažnja u dijelu aproprijacija $i$ interpretacija. U konačnici, rad se u svojoj srži usredotočuje na psalmodičke tekstove u kojima se evidentno prikazuju distinkcije osobnosti i privatnosti u pobožnosti biblijskog psalmista.

\section{Osobnost i privatnost}

Pri istraživanju pobožnosti biblijskog psalmista kao pojedinca važno je načiniti distinkciju pojmova osobno i privatno. Razlikovanje ovih pojmova lako se može previdjeti pa ih se ponekad, neispravno, smatra sinonimima. Pojam privatnosti podrazumijeva viši stupanj povjerljivosti od onoga osobnog i osobnosti. ${ }^{1}$ Razlikovanje osobnog i privatnog u životu biblijskog psalmiste postat će sve očitije kako u obzir uzimamo antropološke dimenzije.

U povijesti kritičkog istraživanja psalama nedovoljno se u obzir uzimala upravo ova distinkcija osobnog od privatnog, što je dovelo do slabijeg razumijevanja cijele problematike, pa i nepotrebnih prijepora u istraživanju biblijskog Psaltira. Ovo se zanemarivalo i stoga što se smatralo da u pojmovima kao što su osobno i privatno postoji pomanjkanje kriterija koji bi bili više znanstveno utemeljeni mada spoj pojmova „,znanstveni kriterij“ $i$,,religioznost“ gotovo da je oksimoron.

1 Za bolje razumijevanje ove problematike prikladno je pružiti čitatelju neke primjere iz svakodnevnog govora. Govorimo o „privatnom vlasništvu“, ali zato ne govorimo o „privatnoj“, već o „osobnoj povredi“. Povreda se, dakle, naziva osobnom, ali ne i privatnom. Antonim pojma „privatno“ je pojam „službeno“ (što još uvijek može biti i osobno!). Svoju osobnu pobožnost psalmist može javno i službeno iskazivati, ali za svoja najintimnija iskustva, emocionalna (i emotivna) stanja povlači se u skrovitost svoje spavaće sobe i postelje, npr. „Iznemogoh od pusta jecanja, u noći postelju plačem zalijevam, suzama ležaj natapam“ (Ps 6,7). 
Smatralo se, ili se smatra, da su manifestacije i iskazi onoga osobnog subjektivni, dok sve ono neosobno smatra se objektivnim (usp. James 1936). ${ }^{2} \mathrm{U}$ dihotomiji subjektivnog od objektivnog ono subjektivno, čini se, postaje "gubitnikom“ pa će subjektivno potonuti u inferioran položaj u odnosu na ono što je objektivno. ${ }^{3}$

Pitanja osobnog i privatnog potiču nas na razmatranje subjekta i subjektivnosti. Tema subjekta (pojedinca) jedna je od središnjih ideja tijekom povijesti književnosti, književnih teorija, filozofije, psihoanalize i hermeneutike, pa potom i teologije.

\section{Osoba i osobnost}

U razmatranju osobe i osobnosti nailazimo na jedan svojevrsni paradoks, naime, riječ osoba nepoznata je u vokabularu biblijskoga hebrejskog jezika. Najbliže shvaćanju koncepta „osobe“ i „osobnosti“ hebrejska je imenica נפשפ (nefeš „duša“). No čini se da se čak i tada nefeš kao pojedinac (subjekt) gotovo nikada ne susreće kao izolirana jedinka. Taj nefeš, osoba - pojedinac, čini se da je prije u interakciji sa zajednicom nego sa samom svojom individualnošću. Kao da je samo neodređeni produžetak kolektivne osobe (usp. Johnson 1961, 7-8).

Uz hebrejski pojam nefeš ideji osobe bliži je pojam פנה (panah „lice“) pa se u semitskom, ali i indoeuropskom načinu razmišljanja pojavljuje pojam „lice“ kao zajednički nazivnik ideje osobe (osobnosti) ${ }^{4} \mathrm{U}$ ovome, fascinantna je etimološka veza između pojmova „lice“ $i$ „osoba“. Aubrey Johnson $(1964,40)$, govoreći o licu i osobnosti, pravo ukazuje na to da lice „iznimno mnogo otkriva o čovjekovim različitim emocijama, raspoloženjima i stanjima“' Nisu samo izrazi lica ono što toliko mnogo otkriva o osobi - licu (lice, ličnost). Osim lica („maska“), različiti

2 William James $(1936,439)$ donosi određene zaključke vezane uz religioznost i osobnost. Religioznost pripada osobnome i osobnoj sudbini, dok znanstveni pristup uvelike isključuje faktor osobnog. Dok se religija vrti oko ,interesa pojedinca u njegovoj privatnoj i osobnoj sudbini“, znanost, s druge strane, „katalogizira svoje elemente i bilježi svoje zakone neovisno o tome kojoj će svrsi služiti te gradi svoje teorije ne obazirući se na to kako će one utjecati na ljudske strahove i sudbine".

3 Fascinantno je da se u temeljima suvremenih prirodnih znanosti ova distinkcija ponešto „stanjuje“, gdje ono osobno više nije toliko radikalno odmaknuto od onoga objektivnog; danas se stoga sve više govori o fizici i metafizici. U povijesti suvremene znanosti o tome najbolje svjedoče istraživanja i zaključci autoriteta kao što su David Bohm, Werner Heisenberg ili Alfred North Whitehead. O tome vidjeti: David Bohm (Casuality and Chance in Modern Physics), Werner Heisenberg (Der Teil und das Ganze) ili Alfred Whitehead (Science and the Modern World).

4 Riječ „osoba“ [engl. person - nap. prev.] dolazi od latinske imenice persona (f.) i/ili grčke riječi $\pi \rho o ́ \sigma \omega \pi$ ov (n.), čije je značenje „lice“. Izvorno se grčka riječ prosopon odnosila na masku koja prekriva lice. U drevnim helenističkim i rimskim kazališnim predstavama postojale su maske za prekrivanje mrtvih; „posmrtne maske“. Postojale su i nebrojene maske koje su predstavljale bilo koji zamislivi lik, emociju, dob i spol. 
pogledi ili okreti lica u određenom smjeru također služe kao pokazatelji svrhe ili namjere osobe. Bog će radi kazne i osvete okrenuti svoje „lice protiv“ svoga naroda (Lev 26,17). ${ }^{5}$ Lice je metonimija pa prosopon („persona, lice, maska“) postaje „Vanjski aspekt određenog objekta, bilo osobnog ili neosobnog““(Johnson 1964, 40). ${ }^{6}$

$\mathrm{U}$ Aronovu blagoslovu, kojim se izriče Božja naklonost nad narodom $(\mathrm{Br}$ 6,24-26), piše: „Neka te Jahve licem svojim obasja, milostiv ti bude!“ $(\mathrm{Br} 6,25)$. Dakle, prosopon, osoba i osobnost jest u licu (פנה); to je Gospodin, koji ili čije lice sja nad njegovim narodom. Lice Božje, to jest Bog sâm, okreće se prema čovjeku dajući mu svoju podršku i život. Ali, Bog može sakriti svoje lice (sebe), što u psalmistu stvara paniku jer „,̌im lice sakriješ, sav se uplašim“ (Ps 30,7) ili „dokle ćeš skrivati lice od mene?" (Ps 13,1). Bog sakriven (deus absconditus) smrtna mu je opasnost pa veli:

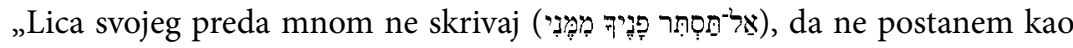

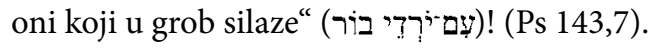

U svojoj Pjesmi ljubavi (1 Kor 13) Pavao ukazuje na to da se krajnja spoznaja Boga događa kroz ljubav koja se iskazuje na razini osobnoga, frazemom prósopon pròs

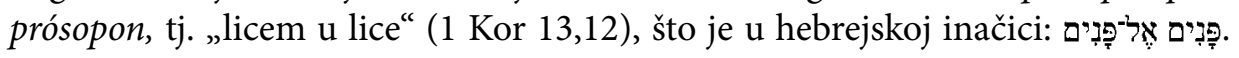
Lice ovdje naznačuje najdublje i najjasnije očitovanje obaju sudionika u susretu. Konačna će spoznaja biti oslobođena svih nepoznanica ili otajstvenih elemenata, ispunjena ljubavlju na najvišem je stupnju osoba, dakle, subjekta-pojedinca.

\section{Subjekt i subjektivnost}

Jedno od vodećih pitanja u narativnoj književnosti odnosi se na identitet i funkciju subjekta, na dramatis personae (dosl. „maska drame“), odnosno na glavnog lika u drami. Kao književni žanr, drama je prije svega i najčešće povezivana s teatrom i onime što bismo danas nazivali "teatralnim“, dakle, s glumcem i teatrom. ${ }^{7}$ Ako pak dramu shvaćamo kruto, tek kao predstavu ograničenu na teatar

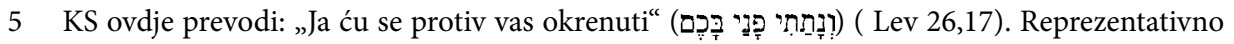
je kako je lingvistički, a zatim i teološki, par lice - osoba izazvao golem razdor u povijesti na relaciji Zapad - Istok. Indikativna je činjenica da su, u kršćansko patrističko doba, kada su započele trinitarne kontroverze oko koncepta Božjeg lica i Krista kao Božje prosopon, lice je predstavljalo očigledni „medij samoizražavanja ili prikazivanja lika“ (Prestige 1952, 55).

6 Culler $(2011,109)$ pruža neke teorije i modele u vezi s položajem i ulogom sebe i subjekta. Posebno navodi opis Michela Foucaulta u psihoanalizi, marksističku teoriju, Queer teoriju itd.

7 Naziv „drama“ prema grčkom jest „radnja“ (usp. Solar 1979, 177). 
i književno-literarnu formu, propustit ćemo uočiti pojedinca kao subjekt u realnom vremenu životnog konteksta. No kada se sagledava problematika osobnosti i privatnosti u biblijskog psalmista, neminovno će se u mnogih, ako ne većine psalama ocrtavati psalmist kao dramatis personae. Naime, u širem smislu drame i dramatis personae odnosi se to na svaku situaciju u kojoj pojedinačni subjekt (pojedinac), ili član grupe, igra ključnu ulogu u kakvoj životnoj epizodi. U biblijskom Psaltiru psalmist se pokazuje kao dramatis personae. ${ }^{8}$

Osim u književnim teorijama, zanimanje za subjekt i pojedinca učestao je u psihoanalizi, hermeneutici, književnoj kritici, feminističkoj kritici, marksističkoj kritici itd. Iz suvremene povijesti zanimljivo je kako se u marksističkoj teoriji određuju subjekt i pojedinac. Jonathan Culler $(2001,109)$ to ovako opisuje: „Teorija marksizma smatra da klasni položaj određuje subjekt: on, ili profitira od rada drugih, ili radi za profit drugih“. Ovo se, donekle, može usporediti i s biblijskim subjektom koji je također određen svojim klasnim položajem, gdje ga religija dodatno još više određuje. Upravo je to prostor u kojem se biblijski psalmist, kao pojedinac, u svojim osobnim i privatnim aspektima, definira i određuje. Jedno od ključnih pitanja tijekom znanstvenih proučavanja psalama bilo je i pitanje subjekta i individualnosti psalmista pojedinca. Naspram predrasude da je pojedinac u kontekstu Svetog pisma samo anonimni dio kolektiva i kolektivne ličnosti, potraga za psalmistom kao privatnom osobom već je dulje vremena prisutna u biblijskim istraživanjima.

\section{Sebstvo: dano ili stvoreno?}

Prije razrade pitanja o psalmistu kao subjektu-pojedincu, njegovoj osobnosti i privatnosti, nešto pažnje mora se posvetiti općenitoj raspravi o različitim pristupima i teorijama subjekta, ali ne samo kao gramatičkog dijela rečenice, već kao ideje o individualnosti pojedinca. Trajno se pred nas stavlja pitanje je li subjekt ili sebstvo „nešto što je dano ili nešto što je stvoreno ... i treba li ga shvatiti u individualnom ili socijalnom smislu“ (Culler 2001, 108).

Culler $(2001,109)$ predlaže četiri smjera ili pitanja u razumijevanju individue kao subjekta. Prvo, na subjekt-pojedinca može se gledati kao na sebstvo, kao na nešto „unutarnje i jedinstveno“. Drugo, Culler subjekt prikazuje kao ono što je „stvoreno“, to je sebstvo „određeno svojim podrijetlom i socijalnim atributima“. Treće, ono je kombinacija prethodnih dviju točaka. Povezuje individuu kao jedinstvenu („unutarnje i jedinstveno“) te individuu koja je „stvorena“, određena svojim podrijetlom. Ova poveznica naglašava promjenjivu prirodu sebstva. Četvrto, Culler naglašava da subjekt postaje individua zauzimanjem „različitih po-

8 Dakako, ako se termin „psalmist“ upotrebi samo kao terminus technicus, pojam „psalmista“ kao pojedinca (subjekt) ostaje tada definicijski nedorečen. 
zicija subjekta“ ili, kako to on kaže, „nizom identifikacija“. Ova Cullerova shema, $s$ jedne strane, koliko upućuje na samu etimologiju pojma subjekt, s druge pak strane svemu ovome može djelomice dodati i nijansu oksimorona. Zašto oksimorona?

Ako stoji ova Cullerova hipoteza da subjekt postaje slobodna individua koja sebe identificira „nizom identifikacija“, kako onda objasniti da već sama imenica u pojmu „subjekt“ dolazi od latinskog subjectio ili subjacceo, u čemu oba izraza zapravo prenose istu ideju - podložnost. Naime, imenični oblik „subjekt“ dolazi od glagola subjectio - „pokoriti se, podčiniti“ ili subjaceo - „ležati ispod“, „u podnožju“. Kako se dosad moglo vidjeti ili očekivati, subjekt se doima kao ono što je slobodno kod subjekta-pojedinca, ono „unutarnje i jedinstveno“. Etimologija samog izraza „subjekt“ čini se pak daje sasvim drugačiju sliku, upućujući na ono što je podčinjeno, a ne na ono što bi bilo jedinstveno i slobodno. ${ }^{9}$

\section{Licem u lice}

U toj etimološkoj nedoumici vezanoj uz izvorno značenje pojma subjekt, nailazimo na pomoć u novozavjetnom tekstu Pavla apostola u njegovoj Himni ljuba$v i$ (1 Kor 13). Svojim, biblijski jedinstvenim iskazom, apostol znantno doprinosi boljem razumijevanju pojmova osobno i privatno kada kaže:

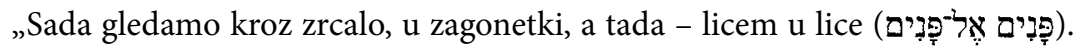
Sada spoznajem djelomično, a tada ću spoznati savršeno, kao što sam i spoznat!“ (1 Kor 13,12).

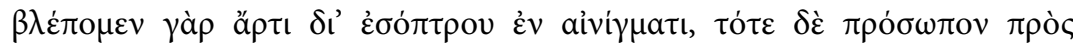

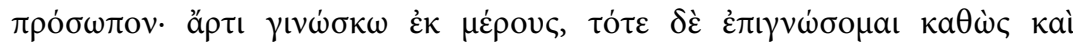
$\dot{\varepsilon} \pi \varepsilon \gamma v \dot{\omega} \sigma \theta \eta \nu$ (1 Kor 13,12).

Apostol ovdje jasno ne kaže koga ili što će tada gledati „licem u lice“, no poznavajući Pavlov teološki opus i njegovu kristocentričnost, izvjesno je da se ovdje ne radi o gnoseološkoj izjavi punine spoznaje, nego o osobnom susretu „licem-ulice“. Nije tada teško pretpostaviti na koga se, a ne na što, ovdje odnosi ovo „licem u lice".

Pavao zapravo izriče tvrdnju kako nema subjekta (pojedinca) bez drugog subjekta (pojedinca). U tom slučaju ne radi se o odnosu nadređenosti i podređenosti (subjecio), nego o korelativnom odnosu. Ne postoji znanje (heb. ידע) bez znanja (spoznaje) onoga drugoga (subjekta). U Pavlovu svijetu nema subjekta bez Boga. U grčkoj inačici futur aktiv $\dot{\pi} \pi \gamma \nu \omega \dot{\sigma o \mu \alpha \iota ~ i ~ p a s i v ~ \varepsilon ̇ \pi \varepsilon \gamma \nu \omega ́ \sigma \theta \eta v ~ i s k a z u j u ~ d v a ~}$ stanja, aktivno („,upoznat ću“) i pasivno (,,i sam sam spoznat“). Oba ova stanja

9 Culler $(2001,109)$ ukazuje na neke teorije i modele u pogledu pozicije i uloge sebstva i subjekta. Posebno navodi prikaz Michela Foucaulta u psihoanalizi; marksističku teoriju, Queer teoriju. 
komplementarno i zajedno izgrađuju narav subjekta (pojedinca). Biblija možda ne može, niti treba, govoriti jezikom 21. stoljeća, ali to ne znači da ta Knjiga ne sadrži relevantna znanja jednakovrijedna, a ponegdje i premoćna modernim teorijama.

\section{Sebstvo i theoria}

Kako bi se psalmista još bolje prikazalo u njegovu osobnom i privatnom životu, važno je razlikovanje između subjekta i objekta. Za to je pak od presudne važnosti dobro poznavati i razumijevati pojam „teorija “. ${ }^{10} \mathrm{Iz}$ antičke grčke metafizike teorija (grč. $\theta \varepsilon \omega \rho o \iota)$ postaje ključan faktor za razlikovanje subjekta od objekta. ${ }^{11}$

Primarno je značenje pojma theoria „promatrati“, „gledati“ nešto. U helenističkoj antici theoros ili theoroi bili su službeni poslanici-promatrači na gradskim festivalima, a theoria (promatranje) je bila njihova glavna zadaća. Theoroi, promatrači, bili su također i diplomatski poslanici u misijama postizanja primirja među sukobljenim gradovima. Njihova je zadaća bila promatranje i procjenjivanje događaja kojima su svjedočili. Subjekt (theoros) kao promatrač ne može podčiniti objekt promatranja ako je na bilo koji način podložan objektu svoga promatranja. Theoros se, dakle, morao distancirati od objekta svoga promatranja (usp. Biti 1997, 385). ${ }^{12}$

Postoji još jedno, ponešto drugačije razumijevanje pojma theoria, a koje podrazumijeva međusobno povezivanje i udruživanje subjekta i objekta. Naime, latinski prijevod grčke riječi theoria je speculatio (lat. specto „promatrati, istraživati"). Pritom se onaj koji promatra, promatrač, naziva spectans, kao u grčkom theoros. Međutim, spectans je također speculator, tj. onaj koji je u očekivanju, poput istraživača. Slijedi stoga ponešto drugačije poimanje između grčkog promatrača (theoros) i latinskog promatrača (spectans). Pritom imamo etimološku igru riječi jer od latinskog korijena glagola specto također dolazi speculum, ogledalo. Ovo znači da spectans, kao promatrač, također izvodi i čin introspekcije. Po mnogočemu ovi se aspekti itekako približavaju poimanju i razumijevanju biblijskog psalmista kao theorosa, ali i spectansa. Biti $(1997,385)$ ovako sažimlje pojmove speculatio i theoria:

10 U suvremenom razmišljanju i poimanju na pojam „teorija“ ponekad se gleda kao nešto što je nepraktično, samo teoretski. Moderna civilizacija više voli jedan drugi pojam, pojam pargmatičnosti opet od grčkog pojma pragma ( $\pi \rho \alpha \gamma \mu \alpha)$ sa značenjem na ono što je "učinjeno“, "praktično“ ili „faktičko“ (od lat. factum, tj. ono što stvarno postoji, stvarno, činjenično).

11 Theoria je složenica nastala od sastavnica: thea "gledište“ i horan „vidjeti“. U svojoj Summa Theologiae Toma Akvinski razlučuje pojmove subiectum i obiectum te govori o odnosu između subjekta i objekta. Navodi pritom da objekt ima sposobnost (ratio) ocijeniti subjekt.

12 Iz naše, ne tako davne povijesti dobro su nam bili poznati takvi poslanici, „mirovni promatrači“, u vrijeme sukoba i među sukobljenim stranama. 
Pojam speculatio, kao latinski prijevod grčkog pojma theoria, podrazumijeva konačno dokidanje razlike između subjekta i objekta u njihovoj potpunoj, zrcalnoj podudarnosti... starogrčki pojam theoria sadrži u sebi podjednako dimenziju promatračkog odvajanja subjekta od objekta i dimenziju samorefleksivnog zrcaljenja jednoga u drugome.

U ovakvom razumijevanju antičkoga grčkog pojma theoria sada su uključena oba aspekta, aspekt promatranja (theoros), gdje se subjekt distancira od objekta, te dimenzija introspekcije i samorefleksije, koja podrazumijeva zrcaljenje između subjekta i objekta (spectans). Oba ova razumijevanja i interpretacije pojma theoria potpuno se podudaraju s iskustvima psalmista, u kojima je igrao, kako ulogu promatrača (theoros) tako i ulogu onoga koji doživljava (spectans). Možemo zaključiti da takozvana teoretska istina nije toliko „teoretska“, već je prije svega, na temelju promatranja i samorefleksije, fenomen života i življenja. U biblijskom Psaltiru, osoban i privatan život pslamista pruža o ovome dobro svjedočanstvo. Isti je taj proces sjajno prikazan i u već navedenoj Pavlovoj Himni ljubavi - konačnoj spoznaji više nije potrebno ogledalo.

\section{Sebstvo i psalmist}

U biblijskim istraživanjima, pogotovo u istraživanjima Psaltira i psalama, na pojedinca (subjekt) dugo se vremena gledalo prije svega samo kao na djelić slagalice umjesto da se prepoznavala osobnost i individualnost psalmista subjekta. Neki istaknuti istraživači psalama rekli bi da je individualna osobnost u biblijskoj kulturi jednaka aroganciji. Jedan od začetnika u istraživanjima psalama, Sigmund Mowinckel (1962, 43), ovako zaključuje: „Biti originalan, izdvojen, osobnost, kojoj se pravo na postojanje zasniva na tome da je drukčija od drugih, drevnim Izraelcima ne bi izgledala kao ideal ili kao cilj koji treba postići, već suprotno tomu, kao ludilo, kao arogancija, nešto abnormalno, ili, prema njihovim vlastitim riječima, kao nepravednost i budalaština" (naglasak dodan).

Promotrimo li pažljivo neke biblijske tekstove, nailazimo na prilično velik broj takvih abnormalnih pojedinaca. Spomenimo ovdje barem dva "arogantna“ biblijska lika, Anu, Samuelovu majku, i patnika Joba. Kada je Ana u svojoj ojađe-

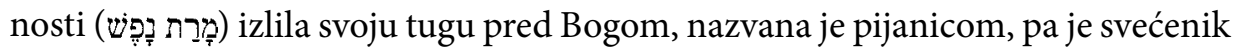
Eli moli da se otrijezni. Pošto su se: „samo usne njezine micale, a glas joj se nije čuo. Zato Eli pomisli da je pijana. I reče joj Eli: 'Dokle ćeš biti pijana? Otrijezni se od vina što je u tebi!'“ (1 Sam 1,10-14). ${ }^{13}$ Kod Joba se pak još žešće prikazuje njegova strana subjekta-pojedinca. Ako je Ana imala svojih frustracija i muka, Job na početku svojih patnji snažno iskazuje svoju individualnost. Na samom

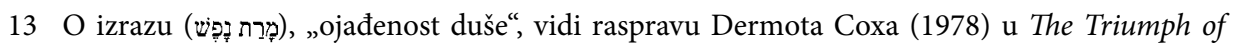
Impotence. 
početku 3. poglavlja on proklinje svoj život: „Job otvori svoja usta i prokle svoj dan. Ne sustežući se nimalo“ (Job 3,1) (prijev. S.Grubišić). Ovdje se ovo „za svoj dan" uglavnom razumijeva kao dan rođenja, osobito s obzirom na to da se u r. 3 izrijekom spominje „dan kad sam se rodio“ (Job 3,3). Treba ovdje uzeti u obzir da se nigdje drugdje u starozavjetnom tekstu „dan“ sam za sebe ne uzima kao dan rođenja. Daleko je vjerojatnije da ovdje Job misli na dan kada je za njega sve krenulo naopako (usp. Clines 1989, 78-79).

Možda ovakve pojedince i epizode treba promatrati naprosto kao svjedočanstvo o općim tradicijama ili tematskim prototipovima. No pokazat ćemo kako je ovakve slučajeve moguće sagledati u svjetlu postavljanja osobne antropologije nasuprot kolektivne antropologije. Po pitanju osobne antropologije, posebno $\mathrm{u}$ slučajevima koje vežemo uz abdominalne izraze, teško je ovakve iskaze smjestiti u okvir kolektivne antropologije. Kako u kontekstu antropologije zajednice govoriti o bubrezima, jetri, utrobi ili maternici kao aspektima antropologije ako ne pojedinca?

\section{Aproprijacija i interpretacija}

Pažljivi čitatelj Psaltira primijetit će da analitičko razumijevanje i interpretacija psalama nije njegov konačni cilj. Pažljivom čitatelju psalama, dakako uz važan analitički aspekt, konačni je cilj aproprijacija psalmodijskih tekstova. To je korak dalje od nužnoga i važnog umno-analitičkog razumijevanja i interpretacije. Aproprijacija je čitateljevo usvajanje teksta kao da je njegov vlastiti, ona je pitanje samoidentifikacije, gdje sam čitatelj postaje doživljavatelj (usp. Schökel 1988, 90).

Jedan od ponajboljih primjera aproprijacije je Isusova samoidentifikacija sa psalmistom. Moćni su prikazi posljednjih tjedana njegova života, iskustva u Getsemanskom vrtu (Ps 22), naposljetku i njegove smrti na križu (Ps 31). Za bolje i primjerenije shvaćanje Psaltira i psalmista, aproprijacija (kao svojevrsno preuzimanje) psalama nudi se kao bolji način ovladavanja Psaltirom i njegova razumijevanja. ${ }^{14}$ Dakako, u svemu ovome prihvaćajući činjenicu da je Psaltir ipak urednička zbirka, sastavljena i prikupljena u liturgijske svrhe, čini se ipak da joj je krajnji cilj bio upravo materijal za aproprijaciju, a ne samo za liturgiju. Sve ovo dovodi nas do pitanja psalmista kao privatne individue i pitanja subjekta aproprijacije.

14 Moguće je složiti se s Alonsom Schokelom $(1988,90)$ u tvrdnji da su biblijski psalmi „ekstreman i gotovo neizbježan slučaj aproprijacije“. 


\section{Osobna pobožnost i privatnost}

\section{Osobna pobožnost}

Osobno se odnosi na sve što je imanentno određenoj osobi, bilo materijalno (npr. imovina) ili nematerijalno (npr. emocije). Osobno je kombinacija emocionalnih obrazaca i obrazaca ponašanja svakog pojedinca. Svijest i samosvijest svega osobnog uključuje i oblike javnog iskaza. Psalmist često žudi za izražavanjem svoje osobne vjere i pobožnosti u javnom bogoslužju. Primjer je Ps 27, u iskrenoj čežnji za Božjom blizinom, psalmist na javnom bogoslužju nastoji potvrditi svoju vjeru i izraziti svoju duboku osobnu pobožnost riječima:

Za jedno molim Jahvu, samo to ja tražim: da živim u domu Jahvinu sve dane života svoga, da uživam milinu Jahvinu i dom njegov gledam (Ps 27,4). ${ }^{15}$

Pojedini komentatori ovu vrstu psalmodijske poezije nazivaju „duhovnom pjesmom“. Gunkel $(1998,346)$ ovaj psalam kategorizira kao „duhovni neobredni psalam" te ga postavlja u kolekciju od dvanaest takvih psalama. ${ }^{16}$ Nije ipak sasvim jasno zašto Gunkel zaključuje da ovakva kolekcija „nema veze s bogoslužjem“. Drugi pak ustrajavaju u stavu da bi se ovaj psalam trebao tumačiti samo u kontekstu liturgije (Craigie 1983, 231). Gunkel zaključuje da je ova kolekcija duhovnih pjesama ili duhovnih neobrednih psalama „primjerena privatnoj upotrebi jer se sastoji od žanrova namijenjenih pojedincu“.

Međutim, drugi u njoj ne prepoznaju zemaljsko prakticiranje osobne pobožnosti, već smatraju da ovi psalmi predočuju „vječno blaženstvo s YHWH-om na nebu“ pa „Božja kuća“ (Jahvin dom) predstavlja božansko nebesko prebivalište (Dahood 1965, 167). Bez obzira na izbor interpretacije, psalmist jasno i snažno iskazuje svoju osobnu pobožnost koju želi i javno pokazati (usp. Ps 27,6b).

\section{Privatnost}

S druge strane, ono što je privatno ograničeno je na određenu dotičnu osobu pa se ne izražava javno. Ono zahtijeva privatan prostor, „zaklonjen“ (lat. privatus) od pogleda javnosti. Hebrejski biblijski tekst i kontekst prepoznaje dva koncepta o svijesti i percepciji onoga što je strogo privatno. Jedan je vezan uz glagol wị (boš „sramiti se“), koji označava nešto što se mora strogo držati za sebe, nešto što je intimno. Ponekad se to odnosi na intimne i privatne dijelove ljudskog tijela (usp. Pnz 25,11). ${ }^{17}$ Drugi je koncept vezan uz glagol לוּט (lut) (la'at „pre-

15 usp. Ps $61,4$.

16 Ps $7 ; 16 ; 17 ; 25 ; 26 ; 27 ; 28 ; 32 ; 33 ; 34 ; 35 ; 37$.

17 „Ako se dvojica potuku, pa žena jednoga pođe da izbavi svoga muža iz šaka onoga koji ga tuče

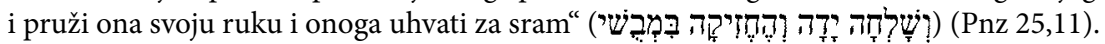


kriti“, „sakriti“, „biti tajnovit“ ili „držati u privatnosti“). ${ }^{18}$ Privatnost je pitanje odvojenosti i tajnosti בלט (balat). U konspirativnoj nakani da se riješi omraženog mu već Davida, kralj Šaul u 1. Samuelovoj 18,22 „zapovjedi svojim slugama

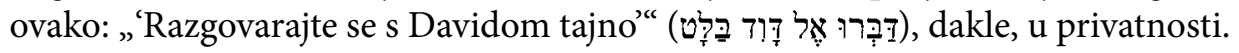
Isus je poticao svoje pobožne sunarodnjake i sljedbenike da istinsku osobnu pobožnost prakticiraju u skrovitosti svoje privatnosti. ${ }^{19} \mathrm{O}$ tome govori Matejevo evanđelje: „Ti kad moliš, uđi u svoju sobu, zatvori vrata i pomoli se svomu Ocu,

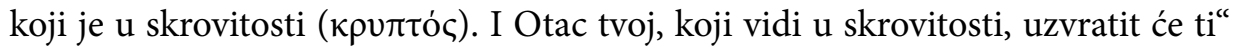

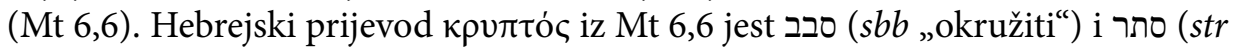
„sakriti se") što jasno naznačuje privatnost. ${ }^{20}$ Upotrebom izraza sastavljenog od dva glagola סתר סביבו ova se privatnost izražava još intenzivnije nego u izvornom grčkom iz Mateja. ${ }^{21}$

Osobna se pobožnost psalmista često prakticira upravo u takvoj skrovitosti; a to može biti prostorno ili vremenski određeno. Prostorno, na njegovu krevetu ili ležaju, u njegovoj sobi (usp. Ps 6; 63). Vremenski, to je moguće u bilo koje vrijeme, i danju i noću (usp. Ps $6 ; 16 ; 17 ; 42 ; 63 ; 77 ; 88$ ).

\section{Zaključne napomene}

Dok je kolektiv prepoznat kao vladajuća društvena organizacija, individua je istovremeno i na istome mjestu prepoznata kao subjekt s kojim treba računati. Ovo je sažeto iskazano riječima Andrea Lacocquea $(1979,235)$ u njegovu komentaru Knjige proroka Danijela:

... čovjek je postao građanin svijeta, ekumene. Na paradoksalan, ali razumljiv način, ovo širenje ljudskih horizonata do univerzalnih dimenzija imalo je za posljedicu atomiziranje društva na individue. $U$ procesu dezintegracije socijalnih struktura, koje su mu bile druga priroda, čovjek se našao sam te, time, jedinstven, sa specifičnim problemima za koje više nisu bila dostatna kolektivna rješenja.

Prema Lacocqueovu sažetku interakcije kolektiva i individue može se zaključiti da kolektivno ,ja“ i kolektivna ličnost (pojedinac, osoba) biblijskog Izraela koegzistira s onime što je osobno i privatno. Nemoguće je prihvatiti da bi se Izraelac

18 Usp. 2 Sam 19,5 לאט je hapax legomena.

19 Takav „privatni skroviti susret“ sa svojim Bogom uključuje odijeljenost - ulazak u privatni / skroviti prostor i zatvaranje vrata za sobom.

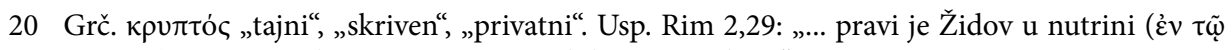

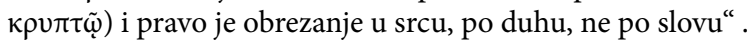

21 Ovo se također odražava u zatvorenosti redovničkih zajednica (lat. claustrum, eng. cloister) koje odvajaju pobožne te ih isključuju iz vanjskog svijeta. 
pojedinac svoju individualnost i subjektivitet imao promatrati kao aroganciju, ludost ili što abnormalno (usp. Mowinckel, 1962, 43). Ovaj rad ukazuje i pokazuje da se ovo dvoje, kolektiv i subjekt u svojoj individualnosti, međusobno ne isključuju, baš naprotiv, oni se komplementarno nadopunjuju (usp. Lacocque 1979, 235). I u ovome se Pavlova Himna ljubavi ponovno pokazuje korisnim primjerom, gdje se subjekt naizmjence koristi kao prvo lice jednine, ali i prvo lice množine. Daljnje istraživanje bi svakako obuhvatilo i neke aspekte izraelske vjere i ranog judaizma da se još bolje naznači i ispita narav židovstva i židovske religije.

\section{Literatura}

Biti, Vladimir. 1997. Pojmovnik suvremene književne teorije, Zagreb, Matica hrvatska

Clines, David. 1989. Job 1-20. Dallas: Word Books.

Cox, Dermot. 1978. The Triumph of Impotence. Roma: Universita Gregoriana Editrice.

Culler, Jonathan. 2001. Književna teorija: vrlo kratak uvod. Zagreb: AGM.

Dahood, Mitchell. 1965. Psalms (I): 1-50. New York: Doubleday.

Gunkel, Herman 1998. Introduction to Psalms: the Genres of the Religious Lyric of Israel.

Macon: Mercer Univerity Press.

James, William. 1936. The Varieties of Religious Experience. New York: The Modern Library.

Johnson, Aubrey. 1961. The One and the Many in the Israelite Conception of God. 2nd edition. Cardiff: University of Wales Press.

Johnson, Aubrey. 1964. The Vitality of the Individual in the Thought of Ancient Israel. 2nd edition. Cardiff: University of Wales Press.

Lacocque, Andre. 1979. The Book of Daniel. London: SPCK.

Mowinckel, Sigmund. 1962. The Psalms in Israel's Worship. Oxford: Basil Blackwell.

Prestige, George Leonard. 1952. God in Patristic Thought. London: SPCK.

Schokel, Luis Alonso 1988. A Manual of Hebrew Poetics. Rome: Pontifical Institute of the Bible.

Solar, Milivoj. 1979. Teorija književnosti. Zagreb: ŠK. 
Danijel Berković and Dean Slavić

\title{
The Personal and the Private in the Piety of the Biblical Psalmist
}

\begin{abstract}
The work discusses a correlative relationship between the notions of the personal and the private in the context of biblical psalmist's piety. Elements of anthropology (heart, soul, face) will obtain considerable importance, particularly the ideas of face and soul (נפש פנה and). These will be corresponding to the Greek idea of $\pi \rho о \sigma о \pi \omega \nu$ (prosopon), person. The authors will insist on the distinction between the ideas of personal and private, but they will also recognize the interdependence of these ideas, in recognition that the individual and the societal, are both contributions in the building of the subject as the self. In Paul's Hymn to Love (1 Cor. 13) the complementary nature between the personal and the private is evident. There we find both passive and active subject's role claiming this double aspect of the human subject - personal and private. Discussion in this work follows longterm debates over the nature of the subject, its personality, and its privacy.
\end{abstract}


